\title{
Empirical Studies on the Relationship between Households' Trust in Government and Agricultural Land Tenancy-Based on the Households Survey in Four Provinces
}

\author{
Yuan Wei ${ }^{1}$, Xu Guanjun ${ }^{2}$, Li Yingzi ${ }^{3} \&$ Jin Jingjing ${ }^{4}$ \\ ${ }^{1}$ Economics Department, Sichuan Administration Institute, Chengdu, China \\ ${ }^{2}$ Business School, Beijing Normal University, Beijing, China \\ ${ }^{3}$ Yibin Tobacco Monopoly Administration, Sichuan Province, China \\ ${ }^{4}$ Education Foundation, Beijing Normal University, Beijing, China \\ Correspondence: Yuan Wei, Economics Department, Sichuan Administration Institute, No. 43, Guanghuacunjie \\ Street, Qing yang District, Chengdu City, Sichuan Province, China. Tel: 86-138-8086-7092. E-mail: \\ yuanwei_sc@163.com
}

Received: December 15, 2015

Accepted: December 31, 2015 Online Published: February 20, 2016

doi:10.5539/ijef.v8n3p33

URL: http://dx.doi.org/10.5539/ijef.v8n3p33

\begin{abstract}
In the premise of the separation of ownership and use right of land in China's rural areas, agricultural land tenancy will be inevitably subject to the influence from the grass-roots government. In order to analyze the role of the trust in government from farmers in land tenancy, we have made a field research on 1305 households in 36 villages randomly selected in Shandong, Hubei, Gansu and Guangxi Provinces and got first-hand data in the year of 2010.In this thesis, we made statistical descriptions of households' trust in government and agricultural land tenancy in field survey areas firstly, and then found that the formers have significant effect on the latter from the empirical analysis. Furthermore, as with the increase of the degree of farmers' trust in government, the ratio of the land tenancy net of final use of the land will become less and less, which means a greater possibility of land leasing. In another word, the more the households' trust in government is, the more inclined the land tenancy will be. In this paper, we have explained the conclusions above and given the relevant policy recommendations from the conclusions.
\end{abstract}

Keywords: households' trust in government, agricultural land tenancy, agricultural land scale operation

\section{Introduction}

Households' trust in government refers to the households' psychological expectations and evaluation of government agencies, government officials, government decisions and government actions. Considering China's rural political system, households' trust in government not only plays a functional role in rural economic development and social stability, but also serves as fundamental basis of the government policies' effectiveness. The trust means recognition and obedience of the power from villagers, and even an important source of governing legitimacy in rural grassroots. Therefore, the study on the current households' trust in government in China's expanded rural areas seems particularly necessary.

Meanwhile, China's agricultural land circulation is closely related to the objective existence of dual economic structure. After entering the new century, the scale of China's agricultural land circulation has been enlarged and the circulation speed has been accelerated, with the proportion of agricultural land tenancy (subcontracting and rent) scale in the agricultural circulation approaching $80 \%$. Obviously, the villagers' trust in government is playing much more important role in the process of agricultural land tenancy, as Rural collective ownership of land which is a vague concept makes the village collective become the leading role in agricultural land tenancy actually, yet village collective is always influenced by local government's guidance. Although after de-collectivization and market economy reforms, households own more power in land tenancy, land operation and other aspects, the government's influence is still unseparated from land tenancy, and this influence performs as households' trust in government further, and therefore these two variables are also major issues to new socialist countryside construction in China. The thesis is to establish the relationship between the households' trust in government and agricultural land tenancy, and then explore the probable influence mechanism of these 
two variables.

\section{Literature Review and Commentary}

There have been a lot of research and studies in the trust in government and agricultural land tenancy respectively. From the typical research in farmers' trust in government, it is generally considered that the long term "dual structure" in the urban and rural areas as with the unfairly "price scissors system" in the industrial and agricultural products due to the household registration system makes Chinese farmers have to endure the unfair treatment which makes the confidence in the local government less and less, therefore the governance is facing a crisis to some extent. The mass incidents and political participation indifference are the two outstanding performances. Firstly, distrust in the local government evolves into confrontation. In the Jiang Shoulin (2007)'s research, "mass incidents" reflects the orientation of the trust in the local government. When farmers have full confidence in the government, they tend to use communication to express their views, but when the trust becomes lower or lose confidence in the government, they would take "urgent force" or "hostile" action to express their anger. Secondly, the distrust in the local government evolves into political participation indifference. Some villagers choose to stay away from politics, like election and such affairs. They may even sell out their votes to express their negative attitude in the political participation indifference, which is a kind of psychological states lack of responsibility and interest in the political life.

The research in the agricultural land tenancy and its role can be summarized into the following three main areas (Shuyi Feng, 2006; Carter \& Olinto, 1998; Carter \& Yao, 1999, 2002): First, the agricultural land tenancy makes the marginal productivity of the land be equal to the land labor endowment ratio, thereby improving the allocative efficiency of resources and the agricultural productivity; Second, land tenancy encourages farmers to develop their comparative advantages of specialized production in agricultural production or non-agricultural employment, which plays a great role in improving households' agricultural or non-agricultural income. Third, it encourages farmers to invest in agricultural land after which the farmers can further make use of the rental fees to invest. However, by reviewing relevant literature on households' trust in government and agricultural land tenancy, we found that very few articles researched on the relationship between households' trust in government and agricultural land tenancy, especially in the research of the effect the households' trust in government on the land tenancy. From this point of view, the research on the relationship between households' trust in government and agricultural land tenancy is not only of academic value, but also of important practical significance.

\section{The Facts from Micro Investigation}

In this paper, we use data and information from the RenErGo research group of Chinese Academy of Social Sciences in Shandong, Hubei, Guangxi, Gansu provinces, 10 counties, 36 villages 1305 household in total to discuss the relationship between the trust in government and agricultural land tenancy. In our research, we take into account some developed and less developed regions, more comprehensive description of the general situation in rural China. As a result, we select Shandong in the east, Hubei in the middle, Gansu in the west and Guangxi in the south, which the natural and economic characteristics of farmland and household can be distinguished from the north and south. 10 counties are: Linyi, Linqu, Qingzhou, Dezhou Decheng district in Shandong province, Enshi, Jianshi in Hubei province, Yuzhong in Gansu province and Mashan, Hepu in Guangxi Zhuang Autonomous Region. The research group chooses 2-6 villages every county, and conducts a questionnaire survey of about 40 households per village, thus, we get 1305 questionnaires from 36 villages to do the research.

\subsection{The Facts of Farmers' Trust in the Government}

The items provided in the questionnaire are to know about the degree of the farmers' trust to different groups, which are shown as follows: brothers and sisters, acquaintances in the village, relatives, government officials, strangers, the parents, religious people, neighbors, acquaintances in other village, classmates and comrade in arms and children. The degree of trust can be scored from $0-100$, which 0 represents distrust and 100 represents the full trust. The degree of trust to different groups from 1305 questionnaire is shown in table 1.

Table 1. The degree of farmers' trust to different groups

\begin{tabular}{ccccccc}
\hline Category & Brothers and sisters & Acquaintances in the village & Relatives & Government officials & Strangers & Parents \\
\hline Degree of trust & 87.95 & 75.30 & 80.85 & 71.41 & 21.01 & 95.38 \\
\hline Category & religious people & neighbors & $\begin{array}{c}\text { acquaintances in } \\
\text { other village }\end{array}$ & $\begin{array}{c}\text { Classmates and } \\
\text { comrade in arms }\end{array}$ & children \\
\hline Degree of trust & 26.47 & 75.83 & 61.35 & 73.92 & 91.52 & \\
\hline
\end{tabular}


From Table 1 we can see that, the trust in parents is the highest, with the score of 95.38. And the lowest is to the religious people and the strangers, with only score of 26.47 and 21.01; the trust in government ranks 8th, with the score of 71.41, more higher than that of acquaintances in other village, neighbors and strangers. Furthermore, the research analyzes the trust in government in different provinces, as Table 2 shows.

Table 2. The trust of farmers in the government in different provinces

\begin{tabular}{lcccc}
\hline & Shandong & Hubei & Gansu & Guangxi \\
\hline The degree of trust to the government & 83.03 & 74.77 & 70.93 & 70.01 \\
\hline
\end{tabular}

As Table 2 shows, the score of Shandong in the east is significantly higher than the score of Hubei in the middle and GanSu, Guangxi in the west, and the score of the west is higher than that of the middle.

\subsection{The Facts of the Agricultural Land Tenancy}

From the constitution of China's arable land, it can be divided into irrigated land, and dry land. The land tenancy in the 4 provinces is shown in Table 3 .

Table 3. The proportion of different types of land in tenancy in 4 provinces

\begin{tabular}{|c|c|c|c|c|c|c|c|c|c|c|c|}
\hline \multirow{2}{*}{ provinces } & \multirow{2}{*}{$\begin{array}{l}\text { Farmers' } \\
\text { household }\end{array}$} & \multicolumn{2}{|c|}{ Land rent-in (\%) } & \multicolumn{2}{|c|}{$\begin{array}{l}\text { Land rent-out } \\
\qquad(\%)\end{array}$} & \multicolumn{2}{|c|}{$\begin{array}{l}\text { Land rent-in as well } \\
\text { as rent-out (\%) }\end{array}$} & \multicolumn{2}{|c|}{$\begin{array}{l}\text { No land tenancy } \\
\qquad(\%)\end{array}$} & \multicolumn{2}{|c|}{ In total $(\%)$} \\
\hline & & $\begin{array}{l}\text { irrigated } \\
\text { land }\end{array}$ & $\begin{array}{l}\text { dry } \\
\text { land }\end{array}$ & $\begin{array}{l}\text { irrigated } \\
\text { land }\end{array}$ & $\begin{array}{l}\text { dry } \\
\text { land }\end{array}$ & $\begin{array}{l}\text { irrigated } \\
\text { land }\end{array}$ & $\begin{array}{l}\text { dry } \\
\text { land }\end{array}$ & $\begin{array}{l}\text { irrigated } \\
\text { land }\end{array}$ & $\begin{array}{l}\text { dry } \\
\text { land }\end{array}$ & $\begin{array}{l}\text { irrigated } \\
\text { land }\end{array}$ & $\begin{array}{l}\text { dry } \\
\text { land }\end{array}$ \\
\hline Shandong & 392 & 13.78 & 0.00 & 2.55 & 0.00 & 0.77 & 0.00 & 77.81 & 100.00 & 100.00 & 100.00 \\
\hline Hubei & 298 & 6.38 & 26.85 & 3.02 & 5.37 & 0.00 & 0.00 & 90.60 & 67.79 & 100.00 & 100.00 \\
\hline Gansu & 307 & 4.23 & 14.66 & 7.82 & 8.14 & 0.00 & 0.00 & 87.95 & 77.20 & 100.00 & 100.00 \\
\hline Guangxi & 308 & 8.12 & 12.34 & 7.14 & 3.25 & 1.30 & 0.00 & 83.44 & 84.42 & 100.00 & 100.00 \\
\hline $\begin{array}{l}\text { Average } \\
\text { proportion }\end{array}$ & (1305) & 8.51 & 12.49 & 4.98 & 3.91 & 0.54 & 0.00 & 84.44 & 53.56 & 100.00 & 100.00 \\
\hline
\end{tabular}

We can see from Table 3, except that Shandong has no dry land lent, the others have both irrigated and dry land tenancy, and Hubei's proportion of dry land lent-in has reached as high as $27 \%$. In order to make a further analysis, we add up the number of irrigated and dry land tenancy respectively, and make a weighted average calculation, as Table 4 shows in the following.

Table 4. The number and proportion of the land tenancy in the 4 provinces

\begin{tabular}{|c|c|c|c|c|c|c|c|c|c|c|}
\hline \multirow{2}{*}{ provinces } & \multirow{2}{*}{$\begin{array}{l}\text { Farmers' } \\
\text { household }\end{array}$} & \multicolumn{2}{|c|}{ Land rent-in } & \multicolumn{2}{|c|}{ Land rent-out } & \multicolumn{2}{|c|}{$\begin{array}{l}\text { Land rent-in as well } \\
\text { as rent-out }\end{array}$} & \multicolumn{2}{|c|}{ No land tenancy } & \multirow{2}{*}{$\begin{array}{l}\text { proportion } \\
(\%)\end{array}$} \\
\hline & & household & $\begin{array}{c}\text { proportion } \\
(\%)\end{array}$ & household & $\begin{array}{c}\text { proportion } \\
(\%)\end{array}$ & household & $\begin{array}{c}\text { proportion } \\
(\%)\end{array}$ & household & $\begin{array}{c}\text { proportion } \\
(\%)\end{array}$ & \\
\hline Shandong & 392 & 54 & 13.78 & 10 & 2.55 & 3 & 0.77 & 325 & 82.91 & 100 \\
\hline Hubei & 298 & 84 & 28.19 & 19 & 6.38 & 1 & 0.34 & 194 & 65.10 & 100 \\
\hline Gansu & 307 & 58 & 18.89 & 48 & 15.64 & 1 & 0.33 & 200 & 65.15 & 100 \\
\hline Guangxi & 308 & 88 & 28.57 & 25 & 8.12 & 7 & 2.27 & 188 & 61.04 & 100 \\
\hline $\begin{array}{l}\text { Average } \\
\text { proportion (the } \\
\text { total number) }\end{array}$ & (1305) & (284) & 21.76 & (102) & 7.82 & (12) & 0.92 & (907) & 69.50 & 100 \\
\hline
\end{tabular}

From Table 4 we can see in the 4 provinces, the proportion of the land rent-in $(21.76 \%)$ is higher than that of 
land rent-out $7.82 \%$ in the tenancy. From the theoretical point of view, the number of farmers who get land rent-in should be equal to that of who get the land rent-out. There are two reasons why the two proportions are significantly different: (1) Each village is a random sample of household, and the number of samples is less than the total number of households, therefore we have missed some sample of farmers who get the land rent-out. (2) In the process of research, some farmers who get land-out may have thought that he can use his agricultural land use right to transfer the land to other people for free, or get little land rent such as $30 \mathrm{yuan} / \mathrm{mu}$, but the farmers who get land rent-in may think the land use is not for free, but in the rent (although less) or payment in kind.

In the 1305 households of farmers, only a handful of farmers have land rent-in as well as land rent-out, but the proportion is too low, with only $1 \%$.The land is rent in as well as rent out may be due to the concentration of agricultural land (by simultaneously renting in and out agricultural land to facilitate farming, even to achieve scale of operations), as well as high to rent in high-quality agricultural land and rent out land with poor quality.

In all households, the number of the farmers who get the land tenancy is 398 , with the average land rent $198 / \mathrm{mu}$, the lowest $30 \mathrm{yuan} / \mathrm{mu}$, and the highest $720 \mathrm{yuan} / \mathrm{mu}$. The average of the east (Shandong as the representative) is 254.93 yuan/mu, and the middle (Hubei as the representative) is $170.38 \mathrm{yuan} / \mathrm{mu}$, and the west is (Gansu and Guangxi as the representatives) is 193.07yuan/mu (Note 1).

\subsection{Statistical Analysis of the Relation between Trust in Government and Agricultural Land Tenancy}

We analyze the trust in government and the type of agricultural land tenancy together, just as shown in Table 5, in the 1305 households of farmers: the number of farmers who neither rent in nor rent out land is 907, and the average trust in government is 69.9; the number of farmers who rent in as well as rent out land is 12 , with average trust level in government is 72.1 ; the number of farmers who only rent in land is 284 , and the trust in government is 76.7 ; the number of farmers who only rent out land is 104 , with trust level is 82.5

Table 5. Types of land tenancy and the degree of trust in government of farmers

\begin{tabular}{ccc}
\hline Types of land tenancy & the number of farmers household & farmers trust in government \\
\hline neither rent in nor rent out & 907 & 69.9 \\
rent in as well as rent out & 12 & 72.1 \\
only rent in & 284 & 76.7 \\
only rent out & 102 & 82.5 \\
\hline
\end{tabular}

From Table 5 we can see, the farmers who rent out land have highest degree of trust in government, with the score of 82.5; and the degree of trust in government of farmers who rent in land ranks second, with the score of 76.7. The farmers who neither rent in nor rent out land have the lowest degree of trust in government, with only 69.9. Therefore, from the statistical data analysis we can say, the farmers' trust in government will probably promote the agricultural tenancy.

\section{The Empirical Analysis of the Effect of Trust in Government on the Agricultural Tenancy}

In our research, we use STATA 10.0 software to make a regression analysis to testify our empirical model. We have collected a set of variables that may affect agricultural land tenancy, and set the model as follows:

$$
\mathrm{R}=\text { Trust }+\alpha_{0}+\alpha_{1} Z^{\mathrm{h}}+\alpha_{2} Z^{\mathrm{q}}+\alpha_{3} \bar{A}+\alpha_{4} Z+\varepsilon
$$

$\mathrm{R}$ represents the ratio of land tenancy to final actual land use, namely $\mathrm{R}=$ (land rent in land -land rent out) / (land from collective contracted + land rent in -land rent out).Theoretically speaking, the range of $\mathrm{R}$ is $(-\infty, 1)$, that is when the farmer rents out all his land but with no land rent in ,the $\mathrm{R}=-\infty$. In our research, we order $\mathrm{R}\{$ when $\mathrm{R}$ is $-\infty\}=$ minimum $\mathrm{R}\{$ households rent out land and also kept some in own hands $\}$.

Trust Represents the farmers' trust in government (score: 0-100);

$Z^{\mathrm{h}}$ Represents the farmers' characteristic variables, such as the annual net income per capita, non-farm employment income, etc.

$Z^{\mathrm{q}}$ Represents fixed variables of farmers, such as geographical factors, average level of education, the proportion of men in population, etc.

$\bar{A}$ Represents the farmer-owned agricultural land endowment, here we use land contracted per capita as representative.

$Z$ Represents the institutional factors, here we use agricultural land guarantee as representative (whether to sign 
the land tenancy contract)

$\alpha_{1} \ldots \alpha_{4}$ Represents undetermined coefficients

$\varepsilon$ Represents the error item.

The total number of households in 4 provinces are 1305, 398 households of farmers have land tenancy. Explained variable and explanatory variable in the model are as shown in the Table 6, and explained variable is the ratio of net tenancy land to the actual agricultural land

Table 6. Statistical description of variables in the model

\begin{tabular}{|c|c|c|c|c|c|}
\hline & Observed & Average & Standard deviation & Minimum & Maximum \\
\hline \multicolumn{6}{|l|}{ Explained variable } \\
\hline the ratio of net tenancy land to the actual agricultural land & 1305 & 0.05 & 0.34 & -4 & 1 \\
\hline \multicolumn{6}{|l|}{ Explanatory variable } \\
\hline farmer's trust in government & 1305 & 75.23 & 24.62 & 0 & 100 \\
\hline the proportion of men & 1305 & 0.53 & 0.15 & 0 & 1 \\
\hline average level of education (year) & 1305 & 7.29 & 2.34 & 0 & 20 \\
\hline non-farm employment income (yuan /per capita/month) & 1305 & 1330.05 & 1543.40 & 0 & 9000 \\
\hline The average annual net income per capita (yuan) & 1305 & 4785.54 & 5217.33 & 222.22 & 42500 \\
\hline The arable land per capita $(\mathrm{mu})$ & 1305 & 1.55 & 1.41 & 0 & 20 \\
\hline land tenancy contracted or not $(y e s=1)$ & 398 & 0.67 & 0.47 & 0 & 1 \\
\hline
\end{tabular}

Table 7 in the following shows the regression result, which is the effect of the trust in government on land tenancy. We can find that farmers' trust in government does have a significant impact on the agricultural land tenancy behavior. Furthermore from data analysis, as the degree of trust in government improves, the ratio of net tenancy land to the actual agricultural land reduces significantly, which means the more the trust in government is, the more inclined the farmers will rent out his farmland.

Table 7. The regression result which is the effect of the trust in government on land tenancy

\begin{tabular}{|c|c|}
\hline explanatory variable & the ratio of net tenancy land to the actual agricultural land \\
\hline \multirow[t]{2}{*}{ farmer's trust in government } & $-0.000880 * * *$ \\
\hline & $(0.000290)$ \\
\hline The regional dummy variables & $(0.00831)$ \\
\hline the proportion of men in households & $0.115^{*}$ \\
\hline \multirow[t]{2}{*}{ average age of adults (years old) } & -0.00695 \\
\hline & $(0.00433)$ \\
\hline \multirow[t]{2}{*}{ Contracted land area per capita $(\mathrm{mu})$} & $-0.0198 * * *$ \\
\hline & $(0.00668)$ \\
\hline non-farm employment income (100yuan/per capita/month) & $(0.000608)$ \\
\hline \multirow[t]{2}{*}{ The average annual net income per capita (1000 yuan) } & $0.00368 * *$ \\
\hline & $(0.00181)$ \\
\hline \multirow[t]{2}{*}{ Constant term } & 0.0366 \\
\hline & $(0.0583)$ \\
\hline Observations number & 1,305 \\
\hline The fitting coefficient & 0.146 \\
\hline
\end{tabular}

Note. $* * *, * * *$ represents significant at the level of $1 \%, 5 \%$ and $10 \%$ respectively.

A possible explanation for these results is that the trust in government is a factor but not the main factor that affects the land tenancy. When the other factors are in certain conditions and farmers have full confidence in 
government, they will use "communication" to adjust their production behavior in order to obtain greater benefits, especially when in the premise of separation of land use rights and ownership, the farmers are willing to adjust its land use rights without changing the ownership, thus no worry that they can't get back their land use right after the expiration of the tenancy. In addition, the conclusion also confirmed that James Kai-sing Kung' research (2002), that farmers often think, "land tenancy will show households don't attach enough importance to land, this may lead to consequences like redistribution of fewer land or inferior land in a certain period of time like 30 years". It is because of the anxiety or lack of trust in government that some farmers would give up land tenancy or transferring, thus impeding the development of agricultural land rental market.

\section{Conclusion}

After empirical discussions from micro level, we drew some main conclusions as follows:

(1) From the field survey data in four provinces, the average index of households' trust in government is 71.41 out of 100 , with the eastern region higher than the central and western regions; $21.76 \%$ of all households have rent in land and $7.82 \%$ of all households have rent out land. The average land rent annually is 198 yuan per mu. Specifically, the land rent in eastern region (Shandong Province) is 254.93 yuan per mu, higher than 170.38 yuan per mu in the middle region (Hubei Province) and 193.07 yuan per mu in the west region (Gansu Province and Guangxi Province).

(2) From analysis, the farmers who rent out land have highest degree of trust in the government, with the score of 82.5; and the degree of trust in government of farmers who rent in land ranks second, with the score of 76.7. The farmers who neither rent in nor rent out land have the lowest degree of trust in government, with only 69.9. Therefore, from the statistical data analysis, the farmers' trust in government will promote the agricultural tenancy

(3) The land tenancy is affected by famer's trust in government, non-farming employment wage, formal institutions, family endowments and other variables. The famer's trust in government is an important but not the main factor.

(4) The farmers' trust in government does have a significant impact on the agricultural land tenancy behavior. Furthermore from data analysis, as the degree of trust in government improves, the ratio of net tenancy land to the actual agricultural land reduces significantly, which means the more the trust in government is, the more inclined the farmers will rent out his farmland.

(5) The explanation of the empirical results is, land tenancy will show households don't attach enough importance to land, this may lead to consequences like redistribution of fewer land or inferior land in a certain period of time like 30 years". It is because of the anxiety or lack of trust in government that some farmers would give up land tenancy or transferring, thus impeding the development of agricultural land rental market, just like James Kai-sing Kung (2002) mentioned.

(6) In the perspective of policy making, the local government may improve the farmers' trust by regulating their own behavior in accordance with the law, which will promote to expand the land tenancy and achieve appropriate scale land operation to contribute to the development of modern agriculture in China.

\section{References}

Carter, M. R., \& Olinto, P. (1998). Do the "Poor but Efficient" Survive in the Land Market? Capital Access and Land Accumulation in Paraguay. Paper presented at the XXI International Congress of the Latin American Studies Association, Chicago.

Carter, M. R., \& Yao, Y. (1999). Specialization Without Regret: Transfer Rights, Agricultural Productivity and Investment in an Industrializing Economy. Madison: University of Wisconsin. http://dx.doi.org/10.1596/1813-9450-2202

Carter, M. R., \& Yao, Y. (2002). Local versus Global Separability in Agricultural Household Models: The Factor Price Equalisation Effect of Land Transfer Rights. American Journal of Agricultural Economics, 84(3), 702-715. http://dx.doi.org/10.1111/1467-8276.00329

James Kai-sing, K. (2002). Off-farm labour markets and the emergence of land rental markets in rural China. Journal of Comparative Economics, 30(2), 395-414. http://dx.doi.org/10.1006/jcec.2002.1780

Shoulin, J. (2007). The research on the trust in the local government based on the farmer' trust. Zhejiang University.

Shuyi, F. (2006). Land Rental Market and Off-farm Employment: Rural Households in Jiangxi Province, China. 
Ph.D. thesis, Wageningen University, Netherlands.

\section{Note}

Note 1. $m u$ : an area Unit; $1 \mathrm{mu}=666.67 \mathrm{~m}^{2}$

\section{Copyrights}

Copyright for this article is retained by the author(s), with first publication rights granted to the journal.

This is an open-access article distributed under the terms and conditions of the Creative Commons Attribution license (http://creativecommons.org/licenses/by/3.0/). 